\title{
Genotype by Environment Interactions of Vegetative Growth Traits of Bread Wheat Genotypes
}

\section{Hafsa Naheed* and Hidayat-Ur-Rahman}

Department of Plant Breeding and Genetics, Faculty of Crop Production Sciences, The University of Agriculture, Peshawar, Pakistan.

Abstract | Determining the amount of genotype by environment interaction (GEI) is an important step in identifying high yielding and stable genotypes for cultivar development. Keeping in view the significance of genotype and environment, a multi environment study was conducted to evaluate the response of genotypes to different cropping systems and environments. The performance of vegetative growth traits of the 40 exotic bread wheat lines was assessed across seven different environments during 2015-16 and 2016-17 growing seasons. The trials were conducted using RCB design at four locations for two years; Research Farm, of the University of Agriculture, Peshawar; Agriculture Research Station, Buner; Agriculture Research Station, Baffa, Mansehra; and Barani Agriculture Research Station, Jarma, Kohat (one year only). Data were recorded on leaf area, plant height, biological yield and straw yield. Highest plant height was recorded for G02, G31 and G11. The exotic lines included in the study generally had more plant height in Peshawar as compared to other locations. The highest maximum mean for leaf area was observed for G17 and CSA while minimum was observed for G03 followed by G33 and G25. Among the seven environments, genotypes on average produced larger flag leaves having maximum leaf area in Peshawar while lowest was observed in Mansehra. For straw yield of the 40 genotypes across seven environments, the highest straw yield of $12547 \mathrm{~kg} \mathrm{ha}^{-1}$ was produced at Mansehra in 2016-17 and the lowest yield of $2440 \mathrm{~kg} \mathrm{ha}^{-1}$ was recorded at Buner in 2017-18. Overall, the genotypes included in the study had more biological yield in Mansehra as compared to other locations. Line G06 and G17 produced maximum biological yield. The lines with desirable characteristics can be used in hybridization programs to combine these characteristics in single line, or to transfer them to other high yielding varieties.

Received | November 20, 2019; Accepted | August 24, 2020; Published | October 07, 2020

*Correspondence | Hafsa Naheed, Department of Plant Breeding and Genetics, Faculty of Crop Production Sciences, The University of Agriculture, Peshawar, Pakistan; Email: hafsaa.naheed@gmail.com

Citation | Naheed, H. and H.U. Rahman. 2020. Genotype by environment interactions of vegetative growth traits of bread wheat genotypes. Sarhad Journal of Agriculture, 36(4): 1020-1032.

DOI | http://dx.doi.org/10.17582/journal.sja/2020/36.4.1020.1032

Keywords | Bread wheat, GEI, Multi environment trial, Vegetative traits, Exotic lines

\section{Introduction}

$\mathrm{B}$ read wheat (Triticum aestivum L.), is one of the most important grain crops used as a staple food in many countries. Currently, wheat is the most widely cultivated (approximately 220 million hectares) and consumed cereal crop. A significant population in many countries is largely dependent on wheat and it fulfills a large part of their nutritional requirements. Globally the consumption and demand of plant materials for use as food, feed and fuel is increasing with the increase in population; furthermore, the use of grain crops for biofuel production has placed an additional pressure on the global grain crops supply 
(Edgerton, 2009). Wheat is used for food, animal feed and an industrial raw material (Nhemachena and Kirsten, 2017). Consequently, both grain yield and biomass are important products of wheat crop. In Pakistan and other Asian countries wheat straw is an important source of animal feed, it is used in combination with green fodder as well as separately when green fodder is limited (Kumar et al., 2013).

The economic yield of grain crops depends on biological yield, which in turn depends on the crop growth rate and crop growth duration; growth rate is primarily affected by assimilates developed in the process of photosynthesis and on the efficiency with which assimilates are partitioned to different plant organs. The grain yield of a crop is therefore dependent upon different aspects of the developmental morphology mostly affecting the photosynthetic machinery and nutrient absorption mechanisms of the plant (Bueno, 1979). Balanced vegetative and reproductive growth and development are important for both biological and economic yields. Vegetative growth is crucial as photosynthetic machinery (source size and activity) is developed during vegetative phase and it also affects reproductive sink capacity and ultimately the seed yield. Plant height is one of the criteria for vegetative growth. Many wheat improvement programs have focused on plant height regulation for increasing grain yield (Wurschum et al., 2015). Flag leaf area is a reliable predictor of amount of assimilates synthesized and thus it is directly linked to crop growth, development and health (Alqudah and Schnurbusch, 2015). Flag leaf photosynthesis serves as the main supply of carbon for grain filling (Bishop and Bugbee, 1998). Flag leaf traits such as length, width and area are reported to be positively and significantly correlated to major yield contributing traits. Wheat genotypes having relatively larger flag leaf size tends to produce more grains spike ${ }^{-1}$ (Zhao et al., 2018). Among leaf morphology and its component traits flag leaf area is reportedly the most yield contributing trait, followed by flag leaf width and flag leaf length (Fan et al., 2015). Maximizing leaf area results in the increase of photosynthetic rate and could be considered an important trait for improvement of yield in wheat (Driever et al., 2014). In countries like Pakistan where yield of majority of crops including wheat is comparatively low, there is a dire need to develop new varieties having better agronomic traits and higher yield.
The performance of a particular variety in the field depends upon the genetics, the environment and the response of the genotype to the environment. The response of each genotype is different in different environments as genes of each genotype interact differently with aerial and below ground environmental factors to translate morphological and physiological aspect of crop growth differently. These variable responses of genotypes to environments are called genotype by environment interaction (GEI). The process of selecting superior lines is complicated by the presence of significant $\mathrm{G} \times \mathrm{E}$ interaction (Sohail et al., 2016), as in majority of the cases the phenotype is not the actual expression of the genotype and selection may not be very effective (Bondari, 1999). For effective and precise selection of genotypes; the genotypes are tested in different environments and multiple seasons (Ahmadi et al., 2012). Hence development of improved wheat varieties that can perform well in different agroenvironmental conditions is one of the most cost effective and powerful approaches to increase crop production (Annicchiarico, 2002).

Knowledge of the magnitude and type of GEI is a pre requisite in any breeding program. Considering the importance of genotype $\times$ environment interactions, this multi-environment trial was conducted to understand the response of the genotypes to the diverse cropping systems and complexes of environments. The specific objectives of the study were to:

1. Evaluate the performance of exotic wheat lines across the different environments.

2. Assess $G \times E$ interaction of exotic wheat lines for vegetative growth traits.

\section{Materials and Methods}

This study was conducted to evaluate genotype $x$ environment interaction and the performance of vegetative growth traits of 35 (Genotype, G1-G35) exotic bread lines and five check cultivars (CSA, Morocco, Atta-Habib, Ghanimat and Siran). The present multi-environment study was conducted at four locations during 2016-17 and three locations during 2017-18 wheat growing seasons of the Khyber Pakhtunkhwa province of Pakistan and the seven combinations of years and locations were considered as seven environments as given below: 


$\begin{array}{llr}\text { Environment } & \text { Location } & \text { Year } \\ \text { E-01 } & \text { Research Farm, The University of Agriculture, Peshawar } & 2016-17 \\ \text { E-02 } & \text { Agriculture Research Station Baffa, Mansehra } & 2016-17 \\ \text { E-03 } & \text { Agriculture Research Station, Amnawar, Buner } & 2016-17 \\ \text { E-04 } & \text { Barani Agriculture Research Station, Jarma, Kohat } & 2016-17 \\ \text { E-05 } & \text { Research Farm, The University of Agriculture, Peshawar } & 2017-18 \\ \text { E-06 } & \text { Agriculture Research Station Baffa, Mansehra } & 2017-18 \\ \text { E-07 } & \text { Agriculture Research Station, Amnawar, Buner } & 2017-18\end{array}$

\section{Design and agronomic practices}

This study was performed using RCB design having three replications at all environments except at E-07 where two replications were used due to limited land availability. Each experimental unit had four rows which were two meters long and row to row distance was 0.3 meter and hence the plot size was $2.4 \mathrm{~m}^{2}$. Ploughing, planking and seed bed preparation was done at proper moisture conditions. The application of recommended fertilizer i.e. $120 \mathrm{~kg} \mathrm{ha}^{-1}$ nitrogen and $80 \mathrm{~kg} \mathrm{ha}^{-1}$ phosphorous for wheat crop was achieved by applying full dose of DAP and half dose of urea at the time of sowing, the remaining half dose of urea was applied at the time of second irrigation. For planting the experiment recommended seed rate of $120 \mathrm{~kg} \mathrm{ha}^{-1}$ was used. The calculated amount of seed for each plot $(28.8 \mathrm{~g})$ was uniformly distributed in four furrows and covered immediately. Uniform standard management practices were followed to raise the crop at all experimental sites.

Data were recorded on the following vegetative growth parameters:

Plant height: At physiological maturity, height of randomly selected representative plants from each experimental unit was measured from ground level to the tip of the spike excluding awns.

Flagleaf area: Length and width of randomly selected flag leaves in each experimental unit was measured. The leaf area was calculated using the following formula developed by Bari et al. (2010) for accurate estimate of leaf area of wheat.

\section{$1 / L A=0.001666+0.27934 / L L-0.0079 / L W+$ $0.43989 /\left(L L^{*} L W\right)+0.01445 /\left(L W^{2}\right)+2.4645 /\left(L L^{2}\right)$}

Where;

LA is leaf area, $\mathrm{LL}$ is leaf length, and $\mathrm{LW}$ is leaf width.

Biological yield: The above ground mass from each plot was harvested separately and weighed after having dried in sun for a week to record biological yield plot $^{-1}$. The following formula was used to calculate biological yield in $\mathrm{kg} \mathrm{ha}^{-1}$.

\section{Biological yield $\left(\mathrm{kg} \mathrm{ha}^{-1}\right)=10,000 \times$ biological yield plot ${ }^{-1}$ Iplot size}

Straw yield: Straw yield was calculated by subtracting grain yield from biological yield.

\section{Statistical analysis}

Analysis of variance: Data from all locations and years were analyzed as combined over the environments. The ANOVA appropriate for randomized complete block design was used for analysis of data to test the significance of genotypes, environments and genotypes $\times$ environments interaction. Least Significant Difference (LSD) was calculated to compare the means of lines with means of the check cultivars.

\section{Results and Discussion}

\section{Plant height}

Analysis of variance combined over years and locations revealed that differences among genotypes and environments were significant at $\mathrm{P} \leq 0.001$; interaction between genotypes and environments was also significant at $\mathrm{P} \leq 0.001$ for plant height (Table 1). These results show that the observable variation present in plant height of these lines is partly due to the differences in the genetic make-up of the lines, partly due to external factors and also due to the differential response of the genetic material of the different lines to the external environmental factors. Maximum portion of observable variation was due to environmental effect (68.31\%), followed by GEI (12.32\%) and genotypic effect (6.74\%). The plant heights of these genotypes were greatly affected by the changes in below ground and aerial environments. 
Table 1: Analysis of variance combined over 7 environments for biological yield and related traits of 40 genotypes of wheat planted in seven environments (at four locations during 2016-17 and three locations during 2017-18 in Khyber Pakhtunkhwa, Pakistan.

$\begin{array}{lllllll}\text { Trait } & \text { SoV§ } & \text { Environments } & \text { Reps }(\mathbf{E}) & \text { Genotypes } & \mathbf{G \times E} & \text { E. Error } \\ & \text { DF } & \mathbf{6} & \mathbf{1 3} & \mathbf{3 9} & \mathbf{2 3 4} & \mathbf{5 0 7} \\ \text { Plant Height }(\mathrm{cm}) & \mathrm{MS} & 9380^{* *} & 159 & 142^{* *} & 43^{* *} & 16 \\ & \text { \% SS } & (68.31) & (2.51) & (6.74) & (12.32) & (10.13) \\ \text { Flag leaf area }\left(\mathrm{cm}^{-2}\right) & \mathrm{MS} & 2406.61^{* *} & 139.51 & 116.71^{* *} & 35.52^{* *} & 17.48 \\ & \text { \% SS } & (38.02) & (4.78) & (11.98) & (21.88) & (23.34) \\ \text { Straw yield }\left(\mathrm{kg} \mathrm{ha}^{-1}\right) & \mathrm{MS} & 9875867801^{* *} & 63216596 & 104473330 \mathrm{~ns} & 485060600^{* *} & 556150550 \\ & \text { \% SS } & (89.09) & (0.57) & (0.94) & (4.38) & (5.02) \\ \text { Biological Yield }\left(\mathrm{kg} \mathrm{ha}^{-1}\right) & \mathrm{MS} & 2967968236^{* *} & 7294976 & 5276254^{*} & 3424799^{* *} & 1815886 \\ & \text { \%SS } & (89.8) & (0.48) & (1.04) & (4.04) & (4.64)\end{array}$

$\$$ "SoV" is source of variation; "Reps (E)" is replications within environments; $G \times E$ is genotypes by environments interaction; "E. Error" is experimental error.

Across all the seven environments included in the study, the highest plant height was attained by G11 $(109.2 \mathrm{~cm})$ in $\mathrm{E}-01$ while the lowest plant height was observed for G33 $(66.4 \mathrm{~cm})$ in E-03 (Table 2). Within environments, plant height of the genotypes ranged from 86.9 to $109.2 \mathrm{~cm}$ in E- $01 ; 87$ to $97 \mathrm{~cm}$ in E- $02 ; 66.4$ to $84.9 \mathrm{~cm}$ in E-03; 70 to $85.7 \mathrm{~cm}$ in E-04; 86.4 to $105.4 \mathrm{~cm}$ in E-05; 73.7 to $95.6 \mathrm{~cm}$ in E-06 and 71.5 to $86.7 \mathrm{~cm}$ in E-07. Mean plant height was $98.4 \mathrm{~cm}$ in E-01, $92.8 \mathrm{~cm}$ in E-02, $76.5 \mathrm{~cm}$ in E-03, $79.1 \mathrm{~cm}$ in E-04, $96.4 \mathrm{~cm}$ in E-05, $82.9 \mathrm{~cm}$ in E-06 and $80.4 \mathrm{~cm}$ in E-07. Mean values for plant height averaged over all locations and years ranged from 81.3 $\mathrm{cm}$ to $91 \mathrm{~cm}$ with a grand mean value of $86.9 \mathrm{~cm}$. G11 exhibited maximum plant height of $91.0 \mathrm{~cm}$ averaged over all environments, followed by $\mathrm{G} 31(90.5 \mathrm{~cm})$ and G02 $(90.4 \mathrm{~cm})$ : G01 had minimum plant height of $81.3 \mathrm{~cm}$; second and third plant height from bottom were recorded for G25 $(81.8 \mathrm{~cm})$ and $\mathrm{G} 21(82.1 \mathrm{~cm})$.

Overall the genotypes included in the study had more plant height in Peshawar (E-01 and E-05) as compared to other locations (Figure 1).

\section{Flag leaf area}

Highly significant differences were observed among the genotypes across the seven environments for flag leaf area. The main effect of environments as well as GEI were significant for flag leaf area (Table 1). The phenotypic variation present in the leaf area of the genotypes was influenced by genetic makeup, environment and the interaction between both; genotypes accounted for $11.98 \%$ of the variation and GEI accounted for $21.88 \%$ of the variation in the leaf area. Maximum variation in the trait was attributed to the environments $(38.02 \%)$. This signifies that environmental changes had a dominant role and significantly affected the leaf area of the genotypes in this study.

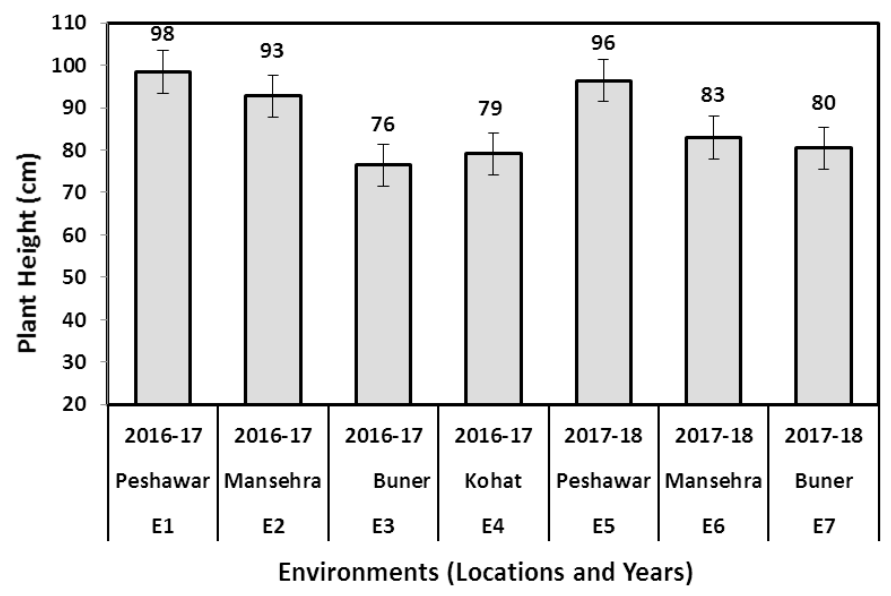

Figure 1: Plant height averaged over 40 genotypes of wheat, in trials conducted in seven environments of Khyber Pakbtunkbrwa, Pakistan during the crop growing seasons of 2016-17 and 2017-18. Error bars are for 1\% LSD $(5 \mathrm{~cm})$.

Flag leaf area based on the average of each genotypes in the seven environments ranged from $16.7 \mathrm{~cm}^{2}$ for G03 at Buner in 2016-17 designated as E-03 to 50.7 $\mathrm{cm}^{2}$ for CSA at Peshawar in 2016-17 designated as E-01 (Table 3). Within environments, flag leaf area ranged from $28.2 \mathrm{~cm}^{2}$ to $50.7 \mathrm{~cm}^{2}$ in E- $01 ; 20.5 \mathrm{~cm}^{2}$ to $36.0 \mathrm{~cm}^{2}$ in E-02; $16.7 \mathrm{~cm}^{2}$ to $32.8 \mathrm{~cm}^{2}$ in E-03; 20.5 $\mathrm{cm}^{2}$ to $43.4 \mathrm{~cm}^{2}$ in E-04; 19.8 to $32.6 \mathrm{~cm}^{2}$ in E-05; $23.0 \mathrm{~cm}^{2}$ to $40.5 \mathrm{~cm}^{2}$ in E-06 and $22.2 \mathrm{~cm}^{2}$ to 32.4 $\mathrm{cm}^{2}$ in E-07. Maximum flag leaf area was observed for CSA in E-01 $\left(50.7 \mathrm{~cm}^{2}\right), \mathrm{G} 02$ in E-02 $\left(36.0 \mathrm{~cm}^{2}\right)$, G10 in E-03 $\left(32.8 \mathrm{~cm}^{2}\right)$, G01 in E-04 $\left(43.4 \mathrm{~cm}^{2}\right)$, 
G02 in E-05 $\left(32.6 \mathrm{~cm}^{2}\right)$, G15 in E-06 $\left(40.5 \mathrm{~cm}^{2}\right)$ and CSA in E-07 $\left(32.4 \mathrm{~cm}^{2}\right)$. Leaf area of the genotypes averaged over all the seven environments ranged from $25.2 \mathrm{~cm}^{2}$ (G03) to $34.3 \mathrm{~cm}^{2}$ (G17 and CSA). Maximum average leaf area was observed for G17 and CSA followed by G01 while minimum was observed for G03 followed by G33 and G25. Among the seven environments, genotypes in Peshawar during 201617 on the average produced larger flag leaves having and maximum leaf area, followed by Mansehra in 2017-18 and Kohat in 2016-17 (Figure 2). Flag leaf area was lowest in Mansehra in 2016-17.

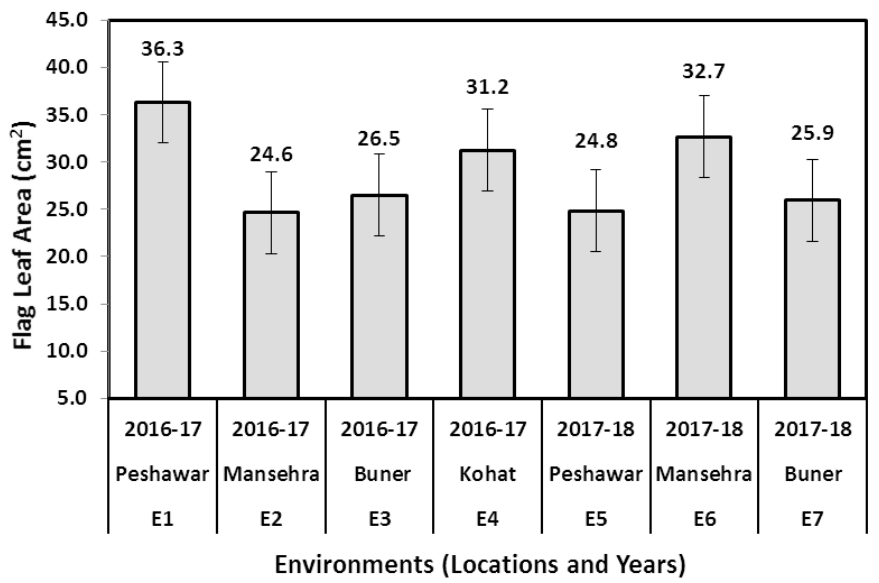

Figure 2: Flag leaf area averaged over 40 genotypes of wheat, in trials conducted in seven environments of Khyber Pakbtunkbwa, Pakistan during the crop growing seasons of 2016-17 and 2017-18. Error bars are for $1 \% \operatorname{LSD}\left(4.3 \mathrm{~cm}^{2}\right)$.

\section{Straw yield}

F-values for environments and genotype $x$ environment interaction sources of variation in combined ANOVA were highly significant for straw yield (Table 1) indicating that straw yield was highly influenced by the environments and the performance of genotypes changed with the changes in the environment. Analysis of variance revealed no significant differences among the average straw yields of the genotypes, which shows that differences among the straw yields of the genotypes did not reach statistically significant level. The GEI accounted for $4.38 \%$ of the total variation, however, its significance showed that the performance of the genotypes was not the same across environments; further partitioning in ANOVA showed that $G \times$ (irrigated versus rain-fed environments) interaction was also significant at the $1 \%$ level of probability. Environments sum of square contributed $89.09 \%$ to the total sum of squares signifying that mean straw yield was more influenced by environment and the phenotypic variation present in the trait is mostly due to the effect of the environments. Further partitioning of the environmental variance into single degree of freedom irrigated versus rain-fed environments contrast in ANOVA showed that the contrast was highly significant.

Perusal of the GEI means showed that straw yield of the genotypes in the seven environments, varied between $1013 \mathrm{~kg}$ ha ${ }^{-1}$ produced by G28 at Buner in 2017-18 (E-07) and $13722 \mathrm{~kg} \mathrm{ha}^{-1}$ produced by G01 at Mansehra in 2016-17 (E-02) (Table 4). Within environments, straw yield of the genotypes ranged from 7583 to $13125 \mathrm{~kg} \mathrm{ha}^{-1}$ in E-01; 10241 to $13722 \mathrm{~kg} \mathrm{ha}^{-1}$ in E-02; 2433 to $6293 \mathrm{~kg} \mathrm{ha}^{-1}$ in E-03; 2731 to 5672 $\mathrm{kg} \mathrm{ha}^{-1}$ in E-04; 5193 to $10067 \mathrm{~kg} \mathrm{ha}^{-1}$ in E-05; 8381 to $12381 \mathrm{~kg} \mathrm{ha}^{-1}$ in E-06 and 1013 to $3900 \mathrm{~kg} \mathrm{ha}^{-1}$ in E-07. Maximum straw yield was observed for G01 in E-01 and E-02 (13125 and $13722 \mathrm{~kg} \mathrm{ha}^{-1}$ respectively), G16 in E-03 (6293 kg ha-1), G02 in E-04 (5672 kg ha 1), G01 in E-05 (10067 kg ha $\left.{ }^{-1}\right)$, G22 in E-06 (12381 $\mathrm{kg} \mathrm{ha}{ }^{-1}$ ) and G19 in E-07 (3900 kg ha $\left.{ }^{-1}\right)$. Though the F-test for the main effect of genotypes was not significant, average straw yield of the genotypes across all seven environments ranged from $6743 \mathrm{~kg} \mathrm{ha}^{-1}$ to $8413 \mathrm{~kg} \mathrm{ha}^{-1}$. Maximum mean straw yield was observed for G01 (8413 kg ha $\left.\mathrm{k}^{-1}\right)$, followed by G06 $\left(8241 \mathrm{~kg} \mathrm{ha}^{-1}\right)$ and G17 (8151 kg ha-1) while minimum was observed for G08 $\left(6743 \mathrm{~kg} \mathrm{ha}^{-1}\right)$, followed by Morocco $(6849 \mathrm{~kg}$ $\left.\mathrm{ha}^{-1}\right)$ and G28 (6907 $\left.\mathrm{kg} \mathrm{ha}^{-1}\right)$.

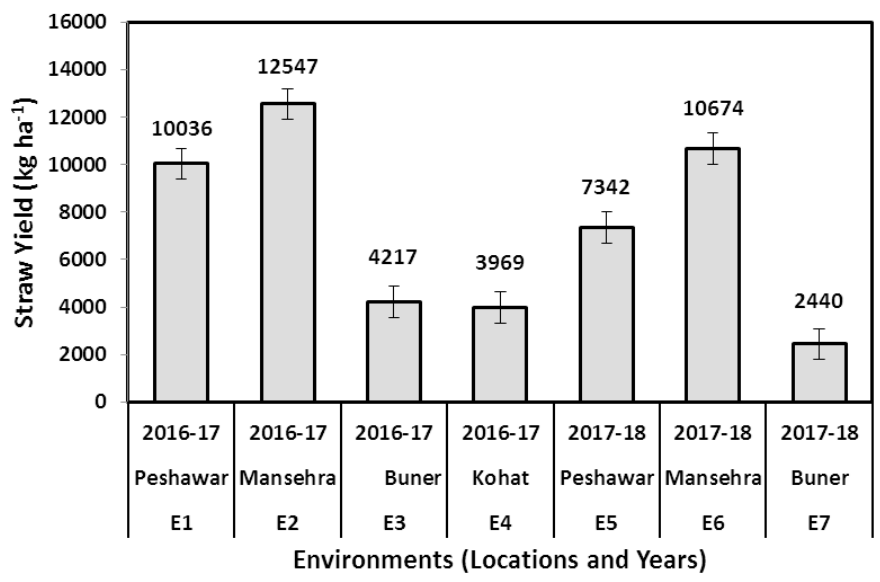

Figure 3: Straw yield averaged over 40 genotypes of wheat, in trials conducted in seven environments of Khyber Pakhtunkhwa, Pakistan during the crop growing seasons of 2016-17 and 2017-18. LSD 5\% for environments is 652 .

Mean straw yield of the 40 genotypes across seven environments revealed that highest straw yield of $12547 \mathrm{~kg} \mathrm{ha} \mathrm{H}^{-1}$ was produced at Mansehra in 2016-17 and the lowest yield of $2440 \mathrm{~kg} \mathrm{ha}^{-1}$ was recorded at Buner in 2017-18 (Figure 3). 
Table 2: Mean plant heights $(\mathrm{cm})$ of 40 wheat genotypes planted in seven environments (four irrigated and three rain-fed) of Khyber Pakbtunkhwa, during 2016-17 and 2017-18.

Genotype

\begin{tabular}{|c|c|c|c|c|c|c|c|c|}
\hline & $\begin{array}{l}\text { Peshawar } \\
2016-17\end{array}$ & $\begin{array}{l}\text { Mansehra } \\
\text { 2016-17 }\end{array}$ & $\begin{array}{l}\text { Buner } \\
2016-17\end{array}$ & $\begin{array}{l}\text { Kohat } \\
2016-17\end{array}$ & $\begin{array}{l}\text { Peshawar } \\
2017-18\end{array}$ & $\begin{array}{l}\text { Mansehra } \\
2017-18\end{array}$ & $\begin{array}{l}\text { Buner } \\
2017-18\end{array}$ & Mean \\
\hline & E1 & $\mathrm{E} 2$ & E3 & $\mathrm{E} 4$ & E5 & E6 & E7 & All Env's \\
\hline $\mathrm{CSA}$ & 92.3 & 92.3 & 79.0 & 75.6 & 97.4 & 77.0 & 81.5 & 85.2 \\
\hline G01 & 86.9 & 93.7 & 69.8 & 71.7 & 86.4 & 85.9 & 71.5 & 81.3 \\
\hline G02 & 103.8 & 95.3 & 76.1 & 83.3 & 97.1 & 95.6 & 76.8 & 90.4 \\
\hline G03 & 105.1 & 92.3 & 72.6 & 74.1 & 94.8 & 86.4 & 74.5 & 86.3 \\
\hline G04 & 102.5 & 94.3 & 77.0 & 78.6 & 97.8 & 86.7 & 83.7 & 88.9 \\
\hline G05 & 103.0 & 88.0 & 84.9 & 83.3 & 94.6 & 73.8 & 81.2 & 87.2 \\
\hline G06 & 101.1 & 96.7 & 76.1 & 78.8 & 99.2 & 83.0 & 74.0 & 87.6 \\
\hline G07 & 107.4 & 89.0 & 76.3 & 80.0 & 105.4 & 87.4 & 83.3 & 90.2 \\
\hline G08 & 96.1 & 90.3 & 74.4 & 80.9 & 94.1 & 91.4 & 79.3 & 87.0 \\
\hline G09 & 100.8 & 92.7 & 77.1 & 85.0 & 99.6 & 89.2 & 82.8 & 89.9 \\
\hline G10 & 90.1 & 96.7 & 72.7 & 76.7 & 100.4 & 83.9 & 78.7 & 85.9 \\
\hline G11 & 109.2 & 97.0 & 78.4 & 78.8 & 102.0 & 86.0 & 82.5 & 91.0 \\
\hline G12 & 98.1 & 95.7 & 79.1 & 80.7 & 101.6 & 83.1 & 83.5 & 89.1 \\
\hline G13 & 100.9 & 90.0 & 77.3 & 83.3 & 100.9 & 86.8 & 82.7 & 89.1 \\
\hline G14 & 90.6 & 92.7 & 80.2 & 80.9 & 87.8 & 82.9 & 83.3 & 85.6 \\
\hline G15 & 99.7 & 94.3 & 78.6 & 82.7 & 88.3 & 88.8 & 84.3 & 88.3 \\
\hline G16 & 98.3 & 94.3 & 78.4 & 83.2 & 96.1 & 81.8 & 81.0 & 87.9 \\
\hline G17 & 108.1 & 91.0 & 75.7 & 85.7 & 97.8 & 81.3 & 81.2 & 89.1 \\
\hline G18 & 94.5 & 93.0 & 80.2 & 83.0 & 100.3 & 77.9 & 80.2 & 87.4 \\
\hline G19 & 102.7 & 94.3 & 78.6 & 80.1 & 102.3 & 83.6 & 84.8 & 89.7 \\
\hline G20 & 92.8 & 87.0 & 79.9 & 81.1 & 93.6 & 80.9 & 81.8 & 85.5 \\
\hline G21 & 91.5 & 94.3 & 72.5 & 75.1 & 89.0 & 75.3 & 74.7 & 82.1 \\
\hline G22 & 87.7 & 92.0 & 77.9 & 73.6 & 88.0 & 79.8 & 79.3 & 82.8 \\
\hline G23 & 99.3 & 88.3 & 78.1 & 73.0 & 94.4 & 73.7 & 77.2 & 83.7 \\
\hline G24 & 95.4 & 91.7 & 78.1 & 85.2 & 94.4 & 85.2 & 77.7 & 87.3 \\
\hline G25 & 89.9 & 94.3 & 72.4 & 72.4 & 88.4 & 75.8 & 78.0 & 81.8 \\
\hline G26 & 106.8 & 95.0 & 76.6 & 82.6 & 92.7 & 86.4 & 80.0 & 89.0 \\
\hline G27 & 89.0 & 90.3 & 77.6 & 77.9 & 92.9 & 78.6 & 82.3 & 84.2 \\
\hline G28 & 98.3 & 92.0 & 73.9 & 83.2 & 100.7 & 88.6 & 86.5 & 89.1 \\
\hline G29 & 104.2 & 96.3 & 81.9 & 83.8 & 98.4 & 85.0 & 73.8 & 89.8 \\
\hline G30 & 90.5 & 89.0 & 74.2 & 70.0 & 94.1 & 77.8 & 82.3 & 82.6 \\
\hline G31 & 105.0 & 97.0 & 77.1 & 80.3 & 95.3 & 90.9 & 86.7 & 90.5 \\
\hline G32 & 95.2 & 94.3 & 77.9 & 82.2 & 100.0 & 88.4 & 84.0 & 89.1 \\
\hline G33 & 93.2 & 91.7 & 66.4 & 74.7 & 96.1 & 81.3 & 74.7 & 83.0 \\
\hline G34 & 94.8 & 92.0 & 74.8 & 80.7 & 91.6 & 80.9 & 82.8 & 85.5 \\
\hline G35 & 100.5 & 96.3 & 75.9 & 79.6 & 100.1 & 81.6 & 81.0 & 88.2 \\
\hline Morocco & 107.0 & 88.0 & 78.1 & 79.9 & 94.7 & 78.1 & 85.0 & 87.4 \\
\hline Atta Habib & 101.7 & 87.3 & 76.5 & 74.8 & 101.0 & 76.9 & 77.8 & 85.5 \\
\hline Ghanimat & 99.5 & 95.3 & 72.3 & 72.7 & 103.3 & 81.1 & 79.7 & 86.6 \\
\hline Siran & 102.5 & 94.0 & 74.6 & 75.4 & 101.4 & 79.0 & 81.0 & 87.2 \\
\hline LSD's§ & 7.7 & 6.2 & 6.0 & 7.0 & 6.3 & 6.6 & 7.6 & 2.5 \\
\hline
\end{tabular}

SLSD $5 \%$ values for each of the seven environments. LSD 5\% for GE is 6.7. 
Table 3: Flag leaf area $\left(\mathrm{cm}^{2}\right)$ of 40 wheat genotypes planted in seven environments (four irrigated and three rain-fed) of Khyber Pakbtunkbwa, during 2016-17 and 2017-18.

Genotype

\section{Environments}

\begin{tabular}{|c|c|c|c|c|c|c|c|c|}
\hline & $\begin{array}{l}\text { Peshawar } \\
\text { 2016-17 }\end{array}$ & $\begin{array}{l}\text { Mansehra } \\
\text { 2016-17 }\end{array}$ & $\begin{array}{l}\text { Buner } \\
\text { 2016-17 }\end{array}$ & $\begin{array}{l}\text { Kohat } \\
2016-17\end{array}$ & $\begin{array}{l}\text { Peshawar } \\
\text { 2017-18 }\end{array}$ & $\begin{array}{l}\text { Mansehra } \\
\text { 2017-18 }\end{array}$ & $\begin{array}{l}\text { Buner } \\
\text { 2017-18 }\end{array}$ & Mean \\
\hline & E1 & $\mathrm{E} 2$ & E3 & $\mathrm{E} 4$ & E5 & E6 & E7 & All Env's \\
\hline CSA & 50.7 & 27.6 & 29.3 & 34.0 & 29.2 & 36.2 & 32.4 & 34.3 \\
\hline G01 & 38.8 & 35.1 & 21.7 & 43.4 & 32.1 & 34.0 & 30.5 & 33.8 \\
\hline G02 & 29.0 & 36.0 & 25.1 & 35.1 & 32.6 & 34.6 & 25.3 & 31.4 \\
\hline G03 & 35.5 & 21.2 & 16.7 & 28.6 & 20.6 & 28.5 & 25.7 & 25.2 \\
\hline G04 & 29.8 & 23.7 & 26.4 & 29.4 & 23.1 & 29.8 & 22.6 & 26.6 \\
\hline G05 & 38.6 & 21.7 & 30.9 & 35.4 & 24.5 & 31.6 & 24.7 & 29.9 \\
\hline G06 & 33.0 & 22.1 & 29.9 & 35.5 & 23.3 & 32.0 & 22.4 & 28.6 \\
\hline G07 & 41.6 & 24.0 & 27.2 & 34.4 & 27.2 & 39.7 & 28.2 & 31.9 \\
\hline G08 & 29.0 & 21.4 & 25.2 & 29.0 & 25.9 & 31.0 & 23.0 & 26.5 \\
\hline G09 & 35.8 & 22.2 & 27.4 & 33.5 & 25.9 & 33.6 & 23.5 & 29.1 \\
\hline G10 & 34.1 & 20.7 & 32.8 & 33.3 & 26.3 & 37.5 & 23.7 & 30.1 \\
\hline G11 & 28.2 & 23.5 & 26.0 & 21.6 & 29.8 & 32.7 & 25.0 & 26.8 \\
\hline G12 & 31.8 & 21.1 & 23.9 & 29.7 & 25.7 & 29.5 & 23.0 & 26.5 \\
\hline G13 & 38.4 & 24.4 & 28.7 & 25.2 & 23.7 & 34.4 & 22.8 & 28.5 \\
\hline G14 & 38.4 & 23.3 & 29.7 & 20.5 & 21.7 & 30.3 & 22.2 & 26.8 \\
\hline G15 & 41.1 & 22.5 & 22.5 & 33.2 & 21.4 & 40.5 & 25.5 & 29.7 \\
\hline G16 & 40.8 & 27.1 & 27.5 & 29.7 & 25.7 & 33.9 & 28.8 & 30.6 \\
\hline G17 & 45.2 & 29.5 & 32.3 & 37.2 & 27.1 & 38.9 & 27.4 & 34.3 \\
\hline G18 & 39.4 & 26.8 & 31.5 & 28.4 & 22.4 & 31.0 & 27.2 & 29.7 \\
\hline G19 & 40.9 & 28.5 & 23.7 & 28.8 & 26.5 & 33.4 & 24.3 & 29.7 \\
\hline G20 & 44.9 & 26.6 & 24.2 & 38.3 & 27.5 & 32.5 & 24.0 & 31.5 \\
\hline G21 & 33.0 & 25.4 & 23.4 & 34.3 & 19.8 & 30.5 & 27.5 & 27.7 \\
\hline G22 & 33.1 & 23.1 & 32.3 & 23.7 & 23.3 & 36.3 & 26.5 & 28.4 \\
\hline G23 & 33.9 & 24.4 & 22.7 & 24.9 & 21.1 & 33.0 & 25.9 & 26.6 \\
\hline G24 & 42.0 & 23.5 & 21.8 & 32.0 & 26.7 & 32.9 & 26.1 & 29.4 \\
\hline G25 & 32.8 & 21.3 & 25.2 & 28.0 & 20.5 & 29.1 & 24.8 & 26.0 \\
\hline G26 & 30.1 & 25.9 & 32.4 & 28.5 & 22.8 & 26.1 & 23.6 & 27.2 \\
\hline G27 & 37.2 & 23.9 & 27.0 & 25.2 & 21.7 & 34.3 & 28.6 & 28.2 \\
\hline G28 & 37.1 & 26.1 & 30.4 & 31.4 & 21.5 & 32.5 & 28.0 & 29.7 \\
\hline G29 & 38.5 & 28.3 & 27.1 & 28.3 & 25.9 & 38.8 & 31.9 & 31.2 \\
\hline G30 & 29.4 & 23.0 & 23.0 & 32.8 & 25.1 & 27.1 & 24.4 & 26.5 \\
\hline G31 & 33.5 & 26.8 & 31.7 & 28.6 & 26.3 & 31.7 & 30.5 & 29.9 \\
\hline G32 & 28.3 & 21.0 & 26.7 & 31.2 & 22.9 & 27.0 & 25.0 & 26.1 \\
\hline G33 & 33.8 & 21.3 & 24.6 & 27.3 & 21.4 & 23.0 & 26.9 & 25.4 \\
\hline G34 & 41.0 & 25.8 & 29.6 & 42.8 & 25.7 & 37.6 & 26.0 & 33.0 \\
\hline G35 & 38.2 & 23.5 & 21.2 & 26.7 & 23.5 & 32.7 & 26.8 & 27.5 \\
\hline Morocco & 36.1 & 25.2 & 28.0 & 43.0 & 24.5 & 34.1 & 24.9 & 31.1 \\
\hline AttaHabib & 40.4 & 22.6 & 22.3 & 30.0 & 27.4 & 33.4 & 27.7 & 29.2 \\
\hline Ghanimat & 30.9 & 20.5 & 23.7 & 34.9 & 28.6 & 33.7 & 25.6 & 28.4 \\
\hline Siran & 36.3 & 25.0 & 24.8 & 31.6 & 22.1 & 27.7 & 24.4 & 27.6 \\
\hline LSD's § & 7.1 & 5.6 & 7.8 & 7.9 & 5.9 & 7.1 & 5.6 & 2.6 \\
\hline
\end{tabular}

\$ LSD $5 \%$ values for each of the seven environments. LSD 5\% for GE is 6.9 . 
Table 4: Straw yield ( $\left.\mathrm{kg} \mathrm{ha}^{-1}\right)$ of 40 wheat genotypes planted in seven environments (four irrigated and three rainfed) of Khyber Pakbtunkbwa, during 2016-17 and 2017-18.

\section{Genotype}

Environments

\begin{tabular}{|c|c|c|c|c|c|c|c|c|}
\hline & $\begin{array}{l}\text { Peshawar } \\
2016-17\end{array}$ & $\begin{array}{l}\text { Mansehra } \\
2016-17\end{array}$ & $\begin{array}{l}\text { Buner } \\
2016-17\end{array}$ & $\begin{array}{l}\text { Kohat } \\
2016-17\end{array}$ & $\begin{array}{l}\text { Peshawar } \\
2017-18\end{array}$ & $\begin{array}{l}\text { Mansehra } \\
2017-18\end{array}$ & $\begin{array}{l}\text { Buner } \\
2017-18\end{array}$ & Mean \\
\hline & E1 & $\mathrm{E} 2$ & E3 & $\mathrm{E} 4$ & E5 & E6 & E7 & All Env's \\
\hline CSA & 10083 & 13352 & 3642 & 3611 & 8574 & 11821 & 2496 & 7912 \\
\hline G01 & 13125 & 13722 & 2436 & 4676 & 10067 & 11019 & 1558 & 8413 \\
\hline G02 & 11639 & 13130 & 3156 & 5672 & 5193 & 11533 & 2183 & 7767 \\
\hline G03 & 10708 & 11944 & 5502 & 2731 & 5789 & 11144 & 1846 & 7357 \\
\hline G04 & 9444 & 11759 & 3189 & 3808 & 5759 & 10992 & 3338 & 7077 \\
\hline G05 & 10236 & 12222 & 3502 & 4240 & 7111 & 10619 & 2858 & 7476 \\
\hline G06 & 11208 & 12704 & 4349 & 4006 & 9319 & 11558 & 2700 & 8241 \\
\hline G07 & 11528 & 12778 & 4637 & 3826 & 7626 & 10891 & 1788 & 7872 \\
\hline G08 & 10069 & 10815 & 3193 & 3960 & 5852 & 9708 & 2033 & 6743 \\
\hline G09 & 9167 & 12815 & 4353 & 4094 & 8970 & 8705 & 2713 & 7487 \\
\hline G10 & 9778 & 13000 & 5747 & 3614 & 8274 & 9348 & 2392 & 7703 \\
\hline G11 & 10181 & 11759 & 4644 & 3724 & 6470 & 11131 & 1963 & 7383 \\
\hline G12 & 9292 & 10241 & 4924 & 4697 & 8259 & 10792 & 1913 & 7422 \\
\hline G13 & 9667 & 12370 & 3773 & 3772 & 8193 & 11350 & 2975 & 7666 \\
\hline G14 & 10694 & 12852 & 4680 & 3946 & 5778 & 10376 & 2792 & 7528 \\
\hline G15 & 10167 & 13685 & 4553 & 3390 & 5707 & 11559 & 3221 & 7681 \\
\hline G16 & 10264 & 12148 & 6293 & 4739 & 7389 & 10678 & 3096 & 8036 \\
\hline G17 & 10750 & 13407 & 5168 & 4286 & 8300 & 10997 & 2150 & 8151 \\
\hline G18 & 10014 & 13204 & 5944 & 4039 & 7756 & 10728 & 1954 & 7948 \\
\hline G19 & 10875 & 13537 & 4771 & 4192 & 8915 & 9208 & 3900 & 8115 \\
\hline G20 & 9875 & 12037 & 4592 & 3549 & 7304 & 10231 & 2588 & 7397 \\
\hline G21 & 9028 & 12889 & 3891 & 3993 & 7774 & 10172 & 1692 & 7331 \\
\hline G22 & 9389 & 11759 & 4397 & 3140 & 7263 & 12381 & 2821 & 7531 \\
\hline G23 & 10403 & 12778 & 4702 & 3853 & 7393 & 11326 & 2433 & 7811 \\
\hline G24 & 10000 & 13389 & 2433 & 4382 & 8259 & 9173 & 1971 & 7343 \\
\hline G25 & 8681 & 13056 & 3964 & 4056 & 6370 & 10014 & 3196 & 7241 \\
\hline G26 & 10333 & 12167 & 4494 & 3783 & 6600 & 10997 & 1771 & 7433 \\
\hline G27 & 8958 & 12481 & 4461 & 4303 & 6563 & 11181 & 3008 & 7493 \\
\hline G28 & 7583 & 12815 & 4549 & 3313 & 5978 & 11135 & 1013 & 6907 \\
\hline G29 & 9417 & 13074 & 4889 & 4317 & 5541 & 11203 & 1425 & 7408 \\
\hline G30 & 9264 & 12815 & 3276 & 4096 & 8133 & 11342 & 3138 & 7653 \\
\hline G31 & 10042 & 13019 & 3876 & 3294 & 7600 & 10972 & 3188 & 7639 \\
\hline G32 & 9917 & 12926 & 4320 & 4085 & 6622 & 10519 & 1996 & 7458 \\
\hline G33 & 9319 & 12944 & 3813 & 3456 & 6078 & 10672 & 1183 & 7061 \\
\hline G34 & 10847 & 12278 & 3736 & 4419 & 7372 & 10758 & 2513 & 7663 \\
\hline G35 & 11000 & 11222 & 4664 & 4203 & 8615 & 10939 & 2788 & 7875 \\
\hline Morocco & 7903 & 11218 & 2607 & 4226 & 7978 & 10126 & 2404 & 6849 \\
\hline AttaHabib & 10569 & 12000 & 3462 & 3571 & 8000 & 10914 & 2396 & 7517 \\
\hline Ghanimat & 9975 & 13093 & 3233 & 4104 & 6726 & 10385 & 3067 & 7434 \\
\hline Siran & 10056 & 12481 & 4864 & 3588 & 8222 & 8381 & 3142 & 7453 \\
\hline LSD’s $§$ & 1941 & 1677 & 1951 & 902 & 2099 & 1764 & 620 & 651 \\
\hline
\end{tabular}

SLSD $5 \%$ values for each of the seven environments. LSD 5\% for GE is 1722. 
Table 5: Biological yield $\left(\mathrm{kg} \mathrm{ha}^{-1}\right)$ of 40 wheat genotypes planted in seven environments (four irrigated and three rain-fed) of Khyber Pakbtunkhwa, during 2016-17 and 2017-18.

\section{Genotype Environments}

\begin{tabular}{|c|c|c|c|c|c|c|c|c|}
\hline & $\begin{array}{l}\text { Peshawar } \\
2016-17\end{array}$ & $\begin{array}{l}\text { Mansehra } \\
\text { 2016-17 }\end{array}$ & $\begin{array}{l}\text { Buner } \\
\text { 2016-17 }\end{array}$ & $\begin{array}{l}\text { Kohat } \\
2016-17\end{array}$ & $\begin{array}{l}\text { Peshawar } \\
\text { 2017-18 }\end{array}$ & $\begin{array}{l}\text { Mansehra } \\
\text { 2017-18 }\end{array}$ & $\begin{array}{l}\text { Buner } \\
2017-18\end{array}$ & Mean \\
\hline & E1 & $\mathrm{E} 2$ & E3 & $\mathrm{E} 4$ & E5 & E6 & E7 & All Env's \\
\hline CSA & 14444 & 17778 & 5309 & 5000 & 12222 & 17500 & 3742 & 11212 \\
\hline G01 & 15417 & 17222 & 3547 & 5833 & 13148 & 15278 & 3400 & 10907 \\
\hline G02 & 13611 & 16296 & 4622 & 6528 & 7037 & 16111 & 3658 & 9997 \\
\hline G03 & 15556 & 15556 & 8236 & 3889 & 8519 & 16944 & 3313 & 10636 \\
\hline G04 & 13333 & 15185 & 4900 & 5556 & 8704 & 15833 & 4950 & 10022 \\
\hline G05 & 14583 & 16111 & 5147 & 5833 & 10185 & 16111 & 4271 & 10623 \\
\hline G06 & 15139 & 16852 & 6638 & 5417 & 12593 & 17778 & 3988 & 11561 \\
\hline G07 & 16528 & 16852 & 6937 & 5139 & 11296 & 16667 & 3546 & 11367 \\
\hline G08 & 14583 & 14444 & 4904 & 5556 & 8704 & 14722 & 3296 & 9767 \\
\hline G09 & 12917 & 17037 & 6776 & 5417 & 12593 & 13889 & 4513 & 10745 \\
\hline G10 & 14028 & 16852 & 8747 & 4722 & 12037 & 15000 & 3854 & 11093 \\
\hline G11 & 14583 & 15370 & 6756 & 5417 & 9630 & 15833 & 3371 & 10475 \\
\hline G12 & 14306 & 13519 & 7436 & 6528 & 11481 & 15833 & 4367 & 10802 \\
\hline G13 & 14028 & 16296 & 5596 & 5694 & 10741 & 16111 & 5425 & 10812 \\
\hline G14 & 14722 & 16667 & 7236 & 5556 & 8519 & 15278 & 4867 & 10683 \\
\hline G15 & 13750 & 18148 & 7264 & 5000 & 7963 & 16944 & 4854 & 10846 \\
\hline G16 & 13333 & 16111 & 9782 & 6389 & 10741 & 15556 & 4879 & 11275 \\
\hline G17 & 16111 & 17407 & 7612 & 5833 & 11852 & 15556 & 3871 & 11543 \\
\hline G18 & 15139 & 17407 & 8678 & 5694 & 10741 & 15556 & 3650 & 11347 \\
\hline G19 & 16111 & 17778 & 6638 & 5833 & 12407 & 13889 & 5842 & 11483 \\
\hline G20 & 14444 & 15556 & 7103 & 5139 & 10556 & 15000 & 4179 & 10588 \\
\hline G21 & 14306 & 16667 & 6402 & 5417 & 10556 & 15278 & 3063 & 10600 \\
\hline G22 & 13472 & 15370 & 6774 & 4306 & 10000 & 17778 & 4617 & 10617 \\
\hline G23 & 15000 & 16481 & 6880 & 5139 & 10926 & 15833 & 5013 & 11040 \\
\hline G24 & 15972 & 17593 & 3744 & 5833 & 12037 & 14444 & 3671 & 10811 \\
\hline G25 & 12639 & 17407 & 6231 & 5417 & 8333 & 14722 & 4875 & 10200 \\
\hline G26 & 15139 & 16481 & 7272 & 5278 & 9259 & 15556 & 3829 & 10731 \\
\hline G27 & 12917 & 16481 & 7039 & 5556 & 9630 & 16389 & 4792 & 10681 \\
\hline G28 & 11944 & 16852 & 6838 & 4583 & 7778 & 16111 & 2663 & 9882 \\
\hline G29 & 13611 & 17037 & 7267 & 5972 & 8148 & 16111 & 2871 & 10509 \\
\hline G30 & 13611 & 16852 & 5031 & 5417 & 11296 & 16389 & 5129 & 10802 \\
\hline G31 & 15000 & 17407 & 5964 & 4861 & 11296 & 16111 & 5188 & 11115 \\
\hline G32 & 14444 & 16852 & 6476 & 5694 & 9074 & 15833 & 3242 & 10580 \\
\hline G33 & 15694 & 16667 & 5647 & 5833 & 9630 & 15000 & 5000 & 10771 \\
\hline G34 & 16111 & 15000 & 7264 & 5833 & 12037 & 16944 & 5304 & 11509 \\
\hline G35 & 11019 & 15023 & 3851 & 5278 & 10556 & 14167 & 4583 & 9442 \\
\hline Morocco & 15000 & 17037 & 4833 & 5000 & 9815 & 16111 & 4438 & 10613 \\
\hline AttaHabib & 14028 & 17222 & 6036 & 4583 & 8148 & 15556 & 2304 & 10066 \\
\hline Ghanimat & 15000 & 15741 & 5329 & 5000 & 11667 & 17222 & 4217 & 10915 \\
\hline Siran & 15000 & 16296 & 7998 & 5139 & 12037 & 17222 & 5146 & 11568 \\
\hline LSD’s $§$ & 2319 & 2062 & 2811 & 1221 & 2877 & 1927 & 732 & 840 \\
\hline
\end{tabular}

\$ LSD $5 \%$ values for each of the seven environments. LSD 5\% for GE is 221 . 


\section{Biological yield}

Probability of $F$-value for genotypes showed significant differences $(\mathrm{P} \leq 0.05)$ among biological yields of the genotypes (Table 1) showing that the genotypes produced different amount of above ground biomass. Main effects of environments and interaction effects were highly significant for biological yield. Maximum contribution to the total sum of squares was made by environments $(89.80 \%)$, followed by GEI (4.04\%) and genotypes (1.04\%). The total variation present in the above ground biomass was mainly due to the effects of the environmental conditions. Significant GEI suggested that fluctuating external factors had dissimilar effects on the genotypes and thus the same genetic makeup expressed differently in different environments.

Across all the environments included in the study, highest biological yield was observed for G15 (18148 $\mathrm{kg} \mathrm{ha}^{-1}$ ) in E-02 while lowest biological yield was observed for Atta Habib (2304 kg ha-1) in E-07 (Table 5). In E-01 biological yield ranged from $11019 \mathrm{~kg} \mathrm{ha} \mathrm{h}^{-1}$ to $16528 \mathrm{~kg} \mathrm{ha}^{-1}$ with a grand mean of $14414 \mathrm{~kg} \mathrm{ha}^{-1}$, in E-02 from $13519 \mathrm{~kg} \mathrm{ha}^{-1}$ to 18148 $\mathrm{kg} \mathrm{ha}^{-1}$ with a grand mean of $16473 \mathrm{~kg} \mathrm{ha}^{-1}$, in E-03 it ranged from $3547 \mathrm{~kg} \mathrm{ha}^{-1}$ to $9782 \mathrm{~kg} \mathrm{ha}^{-1}$ with a grand mean of $6418 \mathrm{~kg} \mathrm{ha}^{-1}$, in E-04 from $3889 \mathrm{~kg}$ $\mathrm{ha}^{-1}$ to $6528 \mathrm{~kg} \mathrm{ha}^{-1}$ with a grand mean of $5403 \mathrm{~kg}$ $\mathrm{ha}^{-1}$, in E-05 from $7037 \mathrm{~kg} \mathrm{ha}^{-1}$ to $13148 \mathrm{~kg} \mathrm{ha}^{-1}$ with a grand mean of $10347 \mathrm{~kg} \mathrm{ha}^{-1}$, in E-06 from 13889 $\mathrm{kg} \mathrm{ha} \mathrm{k}^{-1}$ to $17778 \mathrm{~kg} \mathrm{ha}^{-1}$ with a grand mean of 15854 $\mathrm{kg} \mathrm{ha}^{-1}$ and in E-07 from $2304 \mathrm{~kg} \mathrm{ha}^{-1}$ to $5842 \mathrm{~kg} \mathrm{ha}^{-1}$ with a grand mean of $4194 \mathrm{~kg} \mathrm{ha}^{-1}$. Mean values for biological yield averaged over all locations and years ranged from $9442 \mathrm{~kg} \mathrm{ha}^{-1}$ to $11568 \mathrm{~kg} \mathrm{ha}^{-1}$ with a grand mean of $10756 \mathrm{~kg} \mathrm{ha}^{-1}$. The check cultivar Siran exhibited maximum biological yield averaged over all environments ( $\left.11568 \mathrm{~kg} \mathrm{ha}^{-1}\right)$, followed by G06 and G17 (11561 and $11543 \mathrm{~kg} \mathrm{ha}{ }^{-1}$, respectively). G35 had minimum above ground biomass followed by G08 and G28 (9442, 9767, $9882 \mathrm{~kg} \mathrm{ha}^{-1}$, respectively).

Overall, the genotypes included in the study had more biological yield in Mansehra as compared to other locations. A difference of $3782 \mathrm{~kg} \mathrm{ha}^{-1}$ was observed in the average biological yield of Mansehra and Peshawar whereas a difference of $10857 \mathrm{~kg} \mathrm{ha}^{-1}$ and $10760 \mathrm{~kg} \mathrm{ha}^{-1}$ was observed between Mansehra and Buner and Mansehra and Kohat, respectively (Figure 4). Considering the mean biological yield of all the genotypes across the environments highest biological yield was produced in Mansehra during 2016-17 followed by Mansehra in 2017-18, while lowest average biological yield was produced in Buner in 2017-18.

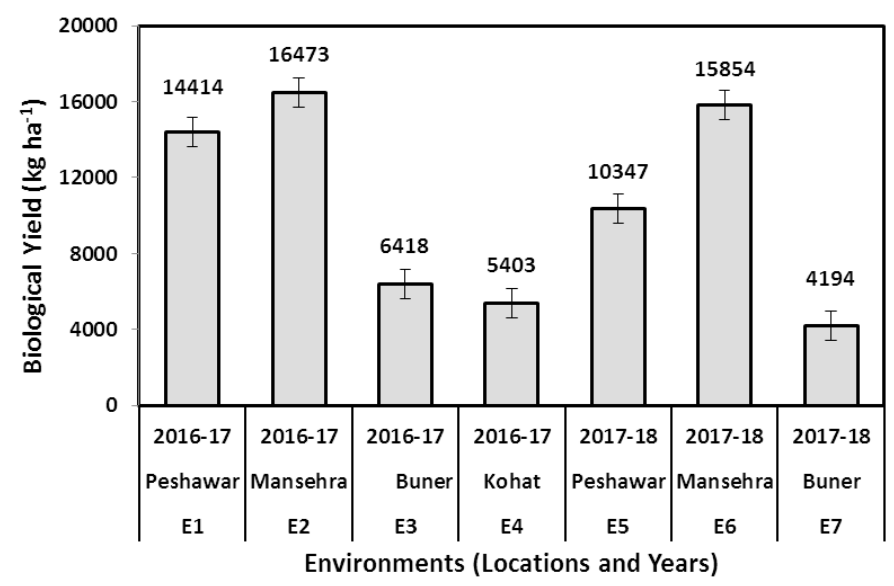

Figure 4: Biological yield averaged over 40 genotypes of wheat, in trials conducted in seven environments of Khyber Pakhtunkhwa, Pakistan during the crop growing seasons of 2016-17 and 2017-18. Error bars are for 1\% LSD (772).

The increase in agriculture production in recent past few decades has generally been in pace with the demands however the yields of a number of crops are reaching a plateau (Raines, 2011). The current scenario of rapidly increasing population and climate change effects is resulting in more pressure on the production of agriculture crops. One important element of plant productivity that is not much used directly to select for improved yield is photosynthesis (Raines, 2011). Photosynthetic products are the primary elements of plant productivity, increasing photosynthetic rate is considered an important trait for increasing biomass and biological yield (Parry et al., 2011; Zhu et al., 2010). Previous studies show that agronomic traits such as plant height, harvest index and total biomass have also contributed to improvement in grain yield (Gao et al., 2017). In the present study, exotic bread wheat lines were evaluated for vegetative growth traits, as total biomass is a function of the total photosynthetic activities of the plant (Driever et al., 2014) and flag leaf area has been identified as valuable trait in breeding programs and a major contributor to grain yield (Alqudah and Schnurbusch, 2015; Driever et al., 2014).

Breeding and selection for ideal plant traits to increase crop production is challenging due to the presence of genotype $\times$ environment interactions (Sohail et al., 2016; Sharma, 1993). For assessing performance of genotypes, they are generally tested over a range of different environments to evaluate the variation in performance in diverse set of conditions (Ahmadi et al., 2012) as the accuracy of independent field trials is 
low (IRRI, 2006) and the $\mathrm{G} \times \mathrm{E}$ interactions hampers the actual performance of the genotypes. In the present multi-environment trial, pooled analysis of variance showed that the main effects of genotype and environment were significant for plant height, leaf area and biological yield and for the straw yield the main effect of the environment was significant whereas the main effect of the genotypes was statistically not significant (Table 1). These results indicate that the genetic makeup of the genotypes as well as the environmental conditions were responsible for the variation observed in the vegetative growth traits of the genotypes. For all the studied traits main effect of the environments was an important source of variation as indicated by the higher contribution of environment sums of squares to the total sum of squares. This shows that the environments in which the genotypes were tested were diverse and had significantly affected the performance of the genotypes.

Plant height is a measure of vertical growth and it is needed to place leaves at different positions for proper light interception and photosynthesis, however, very tall varieties are prone to more lodging under irrigated conditions and very short varieties do not perform well under limited water conditions. Moreover, wheat genotypes with plant height reduced to a certain level has increased genetic gains in wheat and has significantly contributed to increased wheat productivity globally (Tshikunde et al., 2019; Zhang et al., 2016). Plant height in this study was affected by environment, genotypes and $\mathrm{G} \times \mathrm{E}$ interaction. Plant height in different environments ranged from 76 to $98 \mathrm{~cm}$; average height of the different genotypes ranged from 83 to $91 \mathrm{~cm}$, in the GE two-way table plant height ranged from 66 to $109 \mathrm{~cm}$. G02, G31 and G11 produced maximum mean plant height (Table 2). Measuring the leaf area of plants is important for measuring growth and vigor of plants and leaf area especially the flag leaf area is the primary source of energy and mass exchange between the atmosphere and plants (Fang and Liang, 2008). Leaf area is measured in plants to evaluate processes such as canopy evapo-transpiration, biomass accumulation and photosynthesis (Ahmad et al., 2015). Flag leaf area is important as it contributes major part of assimilates for grain filling and thus contributes to yield. Leaf area is considered to be an indicator of crop growth, development, and plant health, and has a strong relationship with these traits in wheat and barley (Alqudah and Schnurbusch, 2015). Several studies report that appropriate flag leaf size could promote development of high grain yield potential (Zhao et al., 2018). Leaf area of the genotypes as averaged over all seven environments ranged from 25.2 to $34.3 \mathrm{~cm}^{2}$. Maximum mean leaf area was observed for G17 and CSA followed by G01 while minimum was observed for G03 followed by G33 and G25 (Table 3).

Wheat straw is an important component of the crop, it serves as a main source of animal feed in areas/time of year where green fodder is not available; it is also used in combination with green forage to fulfill the nutritional requirements of the animals (Kumar et al., 2013) especially in Pakistan and other Asian countries. Cereals straw is recognized as a significant source of renewable energy,(Zajac et al.,2013), in some advanced countries like USA, there is an increasing demand for wheat straw by livestock farmers to be used in feed rations (Gross, 2016). Wheat straw also serves as an important raw material for bioethanol (renewable fuel), the use of which can reduce the production of carbon dioxide and also lessen the dependency on fossil fuels (Dai et al., 2016). Wheat straw can also be used for animal bedding, paper making to save trees, cap making, basket making, composting, packing material and mushroom cultivation. In the present study, though the seven single site ANOVAs for the different environments showed significant differences among straw yields of the genotypes (as shown by LSDs in each column for environment in Table 4); main effect of the genotypes in combined ANOVA for straw yield was not significant but the GEI for straw yield was significant indicating that differences were found among the straw yields of the genotypes in the different environments and rankings of the straw yields of the genotypes were different in the different environments with different genotypes producing maximum and higher straw yields in different environments as shown in each column of Table 4, However, the environmental conditions at each site had much greater effect on straw yield of the genotypes (Figure 3).

The above ground biomass known as biological yield is a useful selection criteria for improving grain yield in wheat and it has a high economic value as well (Jimenez-Berni et al., 2018; Sharma, 1993). In developing countries genotypes having high biological yield are more preferred by farmers as such genotypes produce more grains as well as non-grain plant parts (Sharma, 1992). G06 and G17 among the tested lines exhibited maximum above ground biomass 
averaged over all environments. Biological yield of the genotypes differed significantly across environments. Biological yield ranged from $18148 \mathrm{~kg} \mathrm{ha}^{-1}$ for G15 in E-02 to $2304 \mathrm{~kg} \mathrm{ha}^{-1}$ for check line Atta Habib in E-07. The trend of the biological yield produced by the genotypes in different environments showed that majority of the genotypes produced higher biomass in Mansehra and lower in Buner (Figure 4). The reason for low dry matter accumulation in genotypes in Buner could be due to the scarcity of water in early vegetative growth stages.

\section{Conclusions and Recommendations}

Significant differences were found among the genotypes for plant height, leaf area and biological yield whereas there were non-significant differences among the straw yield of the genotypes. Main effects of the environments were also highly significant for all the traits. GEI were significant for all the studied traits showing that performance of the lines varied under different environments. It can be concluded from these results that genetic makeup, environmental differences as well as their interaction were responsible for the phenotypic differences in then genotypes. This has an important implication for wheat breeders and these can be exploited by breeders for variety development and varietal improvement programs. Exotic lines G06 and G17 produced more biological yield; G11, G31 and G02 produced taller plants and G17 and G01 produced larger leaves. Grain yield can be improved by increasing biological yield as it is the product of biological yield and harvest index. These lines can be used in crossing programs to combine desirable traits in single line, or to transfer these traits to other high yielding and superior varieties.

\section{Novelty Statement}

This study highlights the importance of otherwise neglected straw yield and other vegetative growth traits of bread wheat.

\section{Author's Contribution}

Hafsa Naheed: Conducted the experiments, collected, interpreted and analysed the data and wrote the manuscript.

Hidayat-Ur-Rahman: Supervised the research, provided research material, reviewed the manuscript.

\section{Conflict of interest}

The authors have declared no conflict of interest.

\section{References}

Ahmad, S., H. Ali, A. Rehman, R.J.Z. Khan, W.Ahmad, Z. Fatima, G. Abbas, M. Irfan, H. Ali, M.A. Khan and M. Hasanuzzaman. 2015. Measuring leaf area of winter cereals by different techniques: A comparison. Pak. J. Life Soc. Sci., 13(2):117125.

Ahmadi, J., B. Vaezi and M.H. Fotokian. 2012. Graphical analysis of multi-environment trials for barley yield using AMMI and GGE-biplot under rain-fed conditions. J. Plant Physiol. Breed., 2(1): 43-54.

Alqudah, A.M. and T. Schnurbush. 2015. Barley leaf area and leaf growth rates are maximized during the pre-anthesis phase. Agronomy., 5(2): 107129. https://doi.org/10.3390/agronomy5020107

Annicchiarico, P., 2002. Genotype x Environment interactions challenges and opportunities for plant breeding and cultivar recommendations. Food Agric. Organ. U. N. Rome.

Bari, A., A. Ayub and P. Shah. 2010. Nitrogen management for wheat and its residual effect on maize crop. VDM Verlag Dr. Muller $\mathrm{GmbH}$ and Co. KG. Germany.

Bishop, D.L. and B.G. Bugbee. 1998. Photosynthetic capacity and dry mass partitioning in dwarf and semi-dwarf wheat (Triticum aestivum L.). J. Plant Physiol., 153(5-6): 558-565. https://doi. org/10.1016/S0176-1617(98)80204-6

Bondari, K., 1999. Statistical analysis of genotype by environment interaction in agricultural research. Exp. Stat. Coastal Plain Station, Univ. Georgia, Tifton, GA., pp. 31793-0748.

Bueno, A., 1979. Leaf area estimation, growth analysis, and yield evaluation in grain sorghum (Sorghum bicolor L. Moench.). Retrospective Theses and Dissertations, Iowa State University Capstones.

Dai, J., B. Bean, B. Brown, W. Bruening, J. Edwards, M. Flowers, R. Karow, C. Lee, G. Morgan, M. Ottman and J. Ransom. 2016. Harvest index and straw yield of five classes of wheat. Biomass Bioenergy, 85: 223-227. https://doi.org/10.1016/j. biombioe.2015.12.023

Driever, S.M., T. Lawson, P.J. Andralojc, C.A. Raines and M.A.J. Parry. 2014. Natural variation in photosynthetic capacity, growth, and yield in 64 field-grown wheat genotypes. J. Exp. Bot., 65: 4959-4973. https://doi.org/10.1093/jxb/eru253

Edgerton, M.D., 2009. Increasing crop productivity

December 2020 | Volume 36 | Issue 4 | Page 1031 
to meet global needs for feed, food, and fuel. Plant Physiol., 149: 7-13. https://doi.org/10.1104/ pp.108.130195

Fan, X., F. Cui, C.H. Zhao, W. Zhang, L. Yang, X. Zhao, J. Han, Q. Su, J. Ji, Z. Zhao and Y. Tong. 2015. QTL for flag leaf size and their influence on yield-related traits in wheat (Triticum aestivum L.). Mol. Breed, 35: 1-16. https://doi. org/10.1007/s11032-015-0205-9

Fang, H. and S. Liang. 2008. Leaf area index models. Encycl. Ecol., pp. 2139-2148. https://doi. org/10.1016/B978-008045405-4.00190-7

Gao, F., D. Ma, G. Yin, A. Rasheed, Y. Dong, Y. Xiao, X. Xia, X. Wu and Z. He. 2017. Genetic progress in grain yield and physiological traits in Chinese wheat cultivars of southern Yellow and Huai Valley since 1950. Crop Sci., 57: 760-773. https://doi.org/10.2135/cropsci2016.05.0362

Gross, P., 2016. What is the nutrient value of wheat straw? Michigan State University, MSU Extension https://www.canr.msu.edu/news/whats the_nutrient_value_of_wheat_straw accessed 5 September 2019

IRRI, 2006. Rice breeding course. Int. Rice Res. Inst., https://www.knowledgebank.irri.org/ricebreedingcourse/bodydefault.htm\#Lesson_8_Correlation\%20among\%20traits\%20implications $\% 20$ for\%20screening.htm accessed 21 November 2018

Jimenez-Berni,J.A.,D.M.Deery,P.Rozas-Larraondo, A.T.G. Condon, G.J. Rebetzke, R.A. James, W.D. Bovill, R.T. Furbank and X.R. Sirault. 2018. High throughput determination of plant height, ground cover, and above-ground biomass in wheat with LiDAR. Front. Plant Sci., 9: 237-251. https://doi. org/10.3389/fpls.2018.00237

Kumar, S., A.S. Dhindwal and R.K. Ary. 2013. Dry matter and straw yield in wheat as influenced by preceding crops, planting methods and irrigation levels. Forage Res., 39(2): 88-92.

Nhemachena, C.R. and J. Kirsten. 2017. A historical assessment of sources and uses of wheat varietal innovations in South Africa. SA.J. Sci., 113: 1-8. https://doi.org/10.17159/sajs.2017/20160008

Parry, M.A.J., M. Reynolds, M.E. Salvucci, C.A. Raines, P.J. Andralojic, X.G. Zhu, G.D. Price, A.G. Condon and R.T. Furbank. 2011. Raising yield potential of wheat. II. Increasing photosynthetic capacity and efficiency. J. Exp. Bot., 62(2): 453-467. https://doi.org/10.1093/jxb/erq304

Raines, C.A., 2011. Increasing photosynthet- ic carbon assimilation in $\mathrm{C} 3$ plants to improve crop yield: Current and future strategies. Plant Physiol., 155: 36-42. https://doi.org/10.1104/ pp.110.168559

Sharma, R.C., 1992. Analysis of phytomass yield in wheat. Agron. J., 84: 926-929. https://doi. org/10.2134/agronj1992.00021962008400060 $003 \mathrm{x}$

Sharma, R.C., 1993. Selection for biomass yield in wheat. Euphytica, 70: 35-42. https://doi. org/10.1007/BF00029638

Sohail, Q. H. Naheed and R. Mohammadi. 2016. Breeding and genetic enhancement of dryland crops. In: M. Farooq and K. H. M. Siddique (Ed). Innovations in dryland agriculture. Springer Int. Publ. AG, Switzerland. pp. 257-296. https://doi. org/10.1007/978-3-319-47928-6_10

Tshikunde, N.M., J. Mashilo, H. Shimelis and A. Odindo. 2019. Agronomic and physiological traits, and Associated Quantitative Trait Loci (QTL) affecting yield response in wheat (Triticum aestivum L): A Review. Front. Plant Sci., 10: 1428-1443. https://doi.org/10.3389/ fpls.2019.01428

Wurschum, T., S.M. Langer and C.F.H. Longin. 2015. Genetic control of plant height in European winter wheat cultivars. Theor. Appl. Genet., 128: 865-874. https://doi.org/10.1007/s00122$015-2476-2$

Zajac, T., A. Oleksy, A. Stoklosa, A. Klimek-Kopyral and J. Macuda. 2013. Vertical distribution of dry mass in cereals straw and its loss during harvesting. Int. Agrophys., 27: 89-95. https://doi. org/10.2478/v10247-012-0072-0

Zhang, Yu, W. Xu, H. Wang, H. Dong, X. Qi, M. Zhao, Y. Fang, C. Gao and L. Hu. 2016. Progress in genetic improvement of grain yield and related physiological traits of Chinese wheat in Henan Province. Field Crops Res., 199: 117128. https://doi.org/10.1016/j.fcr.2016.09.022

Zhao, C., Y. Bao and X. Wang. 2018. QTL for flag leaf size and their influence on yield-related traits in wheat. Euphytica, 214(11): 209-215. https:// doi.org/10.1007/s10681-018-2288-y

Zhu, X.G., S.P. Long and D.R. Ort. 2010. Improving photosynthetic efficiency for greater yield. Annu. Rev. Plant Biol., 61: 235-261. https://doi. org/10.1146/annurev-arplant-042809-112206 